\title{
Anti-inflammatory Triterpenes from Euonymus alatus Leaves and Twigs on Lipopolysaccharide-activated RAW264.7 Macrophage Cells
}

\author{
Eun Ju Jeong, Ji-Yeong Bae, ${ }^{\dagger}$ Jung-Rae Rho, ${ }^{\ddagger}$ Young Choong Kim,,${ }^{\S}$ Mi-Jeong Ahn, ${ }^{\dagger}$ and Sang Hyun Sung ${ }^{\S}, *$ \\ Department of Agronomy \& Medicinal Plant Resources and Institute of Fusion Biotechnology, \\ Gyeongnam National University of Science and Technology, Jinju 660-758, Korea \\ ${ }^{\dagger}$ College of Pharmacy and Research Institute of Pharmaceutical Sciences, Gyeongsang National University, Jinju 660-751, Korea \\ ${ }^{\star}$ Department of Oceanography, Kunsan National University, Jeonbuk 573-701, Korea \\ ${ }^{\S}$ College of Pharmacy and Research Institute of Pharmaceutical Science, Seoul National University, Seoul 151-742, Korea \\ *E-mail: shsung@snu.ac.kr \\ Received April 10, 2014, Accepted June 5, 2014
}

\begin{abstract}
As a part of ongoing phytochemical research on Euonymus alatus leaves and twigs, we have isolated one new reissantane-type triterpene (1), together with eight known triterpenes, isoarborinol (2), friedelin (3), abruslac-

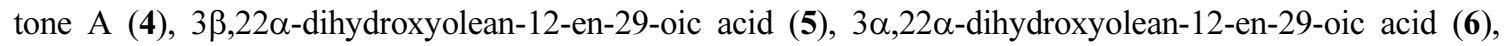
$3 \alpha, 22 \beta$-dihydroxyolean-12-en-29-oic acid (7), 22 $\alpha$-hydroxy-3-oxoolean-12-en-29-oic acid (8), demethylregelin (9). The structure of 1 has been elucidated as 24,24-dimethyl-reissant-7(8),25-dien-3 $\alpha$-ol, by extensive 1D and 2D spectroscopic methods including ${ }^{1} \mathrm{H}-\mathrm{NMR},{ }^{13} \mathrm{C}-\mathrm{NMR},{ }^{1} \mathrm{H}-{ }^{1} \mathrm{H}$ COSY, HSQC, HMBC and NOESY. Anti-inflammatory activities of the isolated compounds were determined as potential regulating excessive inflammatory responses in RAW264.7 macrophage cells. Particularly, abruslactone A (4) and demethylregelin (9) showed the most potent activity, which effectively reduced the expression of iNOS protein and subsequent nitric oxide production induced by lipopolysaccharide in RAW264.7 cells.
\end{abstract}

Key Words : Euonymus alatus, Triterpene, Inflammation, Nitric oxide, RAW264.7

\section{Introduction}

Euonymus alatus (Thunb.) Sieb. (Celastraceae) is a deciduous tree which is commonly known as winged euonymus. The cork cambium on the twigs which is called 'gui-jun woo' has been traditionally used to regulate blood circulation, to relieve pain, to eliminate stagnant blood and to treat dysmenorrheal. Known constituents of E. alatus include sesquiterpenes, sesquiterpene alkaloids, triterpenes, flavonoids and phenolic compounds. ${ }^{1-3}$ Based on such background studies, we previously reported anti-inflammatory compounds isolated from the leaves and twigs of E. alatus which showed the significant inhibitory activities on nitric oxide production in LPS-stimulated RAW264.7 macrophage cells and BV2 microglia cells. ${ }^{4,5}$ Continuous to the previous phytochemical study on E. alatus, we further tried to isolate anti-inflammatory constituents from $\mathrm{CHCl}_{3}$ soluble fraction of the methanolic extract of E. alatus leaves and twigs.

Macrophages are widely distributed in the body and play important role such as host defense, inflammatory regulation and tissue remodeling by providing an immediate defense against foreign agents prior to leukocyte migration. ${ }^{6}$ An effective immune cells, macrophages play pivotal roles in innate and adaptive immune response to pathogens such as phagocystosis, cytokines, bacteria, bacterial products and particulates including lipopolysaccharide (LPS). ${ }^{7-9}$ Upon activation, various growth factors, cytokines and lipid mediators that promote inflammatory process are released. Hence, macrophages are recognized as target cells of a variety of immunosuppressants and anti-inflammatory drugs, leading to acquired immunity. ${ }^{10}$ The pharmacological reduction of LPS-inducible inflammatory mediators in macrophage has been recognized as an effective target for the development of anti-inflammatory drugs or immunosuppressants.

In the present study, we report the isolation and structural elucidation of compounds 1-9 from E. alatus leaves and twigs, and the inhibitory activities of the isolated compounds on nitric oxide (NO) production and the expression of iNOS in LPS-stimulated RAW264.7 cells.

\section{Experimental}

Plant Material. The leaves and twigs of E. alatus were collected in Nambu forest of Seoul National University, Beagwoon Mountain, Gwangyang city, Jeollanam-do, Korea, in September 2007 and authenticated by Dr. Jong Hee Park, professor of Pusan National University. A voucher specimen (CS-99) has been deposited in Herbarium of the Medicinal Plant Garden, College of Pharmacy, Seoul National University, Koyang, Korea.

Extraction and Isolation of Compounds 1-9. The airdried leaves and twigs of E. alatus $(15 \mathrm{~kg})$ were extracted three times for $3 \mathrm{~h}$ each with $80 \% \mathrm{MeOH}(140 \mathrm{~L})$ in room tempearture using an ultrasonic apparatus. Removal of the solvent in vacuo yielded a methanolic extract $(1.2 \mathrm{~kg})$. The methanolic extract was then suspended in distilled water and partitioned successively with $\mathrm{CHCl}_{3}(9 \mathrm{~L})$, EtOAc (9 L), and 
$n$-BuOH $(10 \mathrm{~L})$. The $\mathrm{CHCl}_{3}$ fraction $(112 \mathrm{~g})$ was subjected to column chromatography on a silica gel column using mixtures of $\mathrm{CHCl}_{3}-\mathrm{MeOH}$-Water of increasing polarity as eluents $(100: 4: 1 \rightarrow 50: 4: 1 \rightarrow 25: 4: 1 \rightarrow 15: 4: 1 \rightarrow 10: 5: 1 \rightarrow 5: 4: 1$ $\rightarrow \mathrm{MeOH}$ ) to give 11 fractions (fr. 1 to 11 ). Compound 3 $(420 \mathrm{mg})$ was obtained through recrystallization with $\mathrm{MeOH}$ from fr. 2. Fr. 4 was applied on silica gel column eluting with a gradient of $\mathrm{CHCl}_{3}-\mathrm{MeOH}$ to yield 6 fractions (fr. 4-1 to 46). Compounds $1(160 \mathrm{mg})$ and $2(330 \mathrm{mg})$ were obtained from fr. 4-6 and fr. 4-5, respectively, by recrystallization with $\mathrm{MeOH}$. Fr. 8 was subjected to ODS gel column chromatography with a gradient elution of $\mathrm{MeOH}-\mathrm{H}_{2} \mathrm{O}$ $(20 \% \rightarrow 80 \% \mathrm{MeOH})$ to give eight fractions (fr. 8-1 to 8-8). Fr. 8-6 was chromatographed on silica gel column eluted with $n$-hexane-EtOAc $(1: 1 \rightarrow 1: 5)$ to yield 8 fractions (fr. 86-1 to 8-6-8). Compound 5 (14 mg) was obtained from 8-6-6 by additional $\mathrm{C}_{18}$ RP HPLC $\left(\mathrm{AcCN}-\mathrm{H}_{2} \mathrm{O} 65: 35,2.0 \mathrm{~mL} /\right.$ $\left.\min , 250 \times 10 \mathrm{~mm}, 210 \mathrm{~nm}, t_{\mathrm{R}} 28.01 \mathrm{~min}\right)$. Fr. 8-7 was subjected to silica gel column chromatography eluted with $n$ hexane-EtOAc $(1: 1 \rightarrow 1: 5)$ and yielded seven subfractions (fr. 8-7-1 to 8-7-7). Compounds $8(4.4 \mathrm{mg})$ and $9(5.2 \mathrm{mg})$ were isolated by $\mathrm{C}_{18} \mathrm{RP} \mathrm{HPLC}\left(\mathrm{AcCN}-\mathrm{H}_{2} \mathrm{O} 70: 30,2.0 \mathrm{~mL} /\right.$ $\min , 250 \times 10 \mathrm{~mm}, 210 \mathrm{~nm}, t_{\mathrm{R}} 25.96$ and $t_{\mathrm{R}} 27.54 \mathrm{~min}$ ) from fr. 8-7-6. Silica gel column chromatography of fr. 8-8 with a gradient elution of $n$-hexane-EtOAc afforded six subfractions (fr. 8-8-1 to 8-8-6). Fr. 8-8-1 was further purified by recrystallization with $\mathrm{MeOH}$ to yield compound $4(8.2 \mathrm{mg})$. Compounds $6(3.7 \mathrm{mg})$ and $7(4.5 \mathrm{mg})$ were isolated by $\mathrm{C}_{18}$ RP HPLC ( $\mathrm{AcCN}-\mathrm{H}_{2} \mathrm{O} 70: 30,2.0 \mathrm{~mL} / \mathrm{min}, 250 \times 10 \mathrm{~mm}$, $210 \mathrm{~nm}, t_{\mathrm{R}} 39.04$ and $t_{\mathrm{R}} 45.36 \mathrm{~min}$ ) from fr. 8-8-6.

24,24-Dimethyl-reissant-7(8)-25-dien-3a-ol (1). White amorphous powder, HREIMS $\mathrm{m} / \mathrm{z} 454.4202[\mathrm{M}]^{+}$(calcd. for $\left.\mathrm{C}_{32} \mathrm{H}_{54} \mathrm{O}, 454.4175\right) ; \mathrm{mp} 219-220{ }^{\circ} \mathrm{C},[\alpha]_{\mathrm{D}}^{25}+72.0^{\circ}(c 1.0$, $\mathrm{CHCl}_{3}$ ); IR (KBr) $v_{\max } \mathrm{cm}^{-1}: 3477,2943,2871,1457,1377$, 758; NMR data, see Table 1.

Cell Cultures. RAW264.7 macrophage cells were obtained from Korea Cell Line Bank (Seoul, Korea). The cell line was maintained in DMEM containing $20 \mathrm{mM}$ HEPES, 2 $\mathrm{mM}$ L-Glutamine, $10 \%$ FBS with penicillin $(100 \mathrm{IU} / \mathrm{mL})$ and streptomycin $(10 \mathrm{mg} / \mathrm{mL})$ at $37^{\circ} \mathrm{C}$ in a humidified atmosphere of $95 \%$ air- $5 \% \mathrm{CO}_{2}$.

Determination of NO Content. RAW264.7 cells were seeded in 48 well plates $\left(1 \times 10^{5}\right.$ cells/well $)$ and incubated at $37^{\circ} \mathrm{C}$ for $24 \mathrm{~h}$. Then, the cell culture was washed and the medium was replaced with Griess medium to remove any trace of phenol red, and treated with test sample for $1 \mathrm{~h}$ before exposure to $0.1 \mathrm{mg} / \mathrm{mL}$ of LPS. After $24 \mathrm{~h}$ incubation, nitrite in culture medium was measured to assess $\mathrm{NO}$ production in RAW264.7 cells using Griess reagent. The absorbance at $550 \mathrm{~nm}$ was measured on a microplate reader and the concentration was determined using nitrite standard curve.

Estimation of Cell Viability. After $100 \mathrm{~mL}$ of sample aliquot was collected for Griess assay, MTT $(0.2 \mathrm{mg} / \mathrm{mL})$ was directly added to cultures, followed by incubation at 37 ${ }^{\circ} \mathrm{C}$ for $2 \mathrm{~h}$. The supernatant was then aspirated and $100 \mathrm{~mL}$ of DMSO was added to dissolve the formazan. After in- soluble crystals were completely dissolved, absorbance at $540 \mathrm{~nm}$ was measured using a microplate reader. Data were expressed as percent cell viability relative to control cultures.

Western Blotting. RAW264.7 cells were plated overnight in 6 -well plates at a density of $1 \times 10^{6}$ cells per well. The medium was changed to fresh one and treated with test sample for $1 \mathrm{~h}$ before exposure to $0.1 \mathrm{ug} / \mathrm{mL}$ of LPS. After 8 $\mathrm{h}$ incubation, cells were washed twice with phosphatebuffered saline (PBS). The washed cell pellet was lysed in $200 \mu \mathrm{L}$ of extraction lysis buffer (50 mM HEPES $\mathrm{pH} 7.0$, $250 \mathrm{mM} \mathrm{NaCl}, 5 \mathrm{mM}$ EDTA, $5 \mathrm{mM} \mathrm{NaF}, 0.5 \mathrm{mM}$ sodium orthovanadate, protease inhibitor cocktail, $1 \%$ glycerol) and incubated for $30 \mathrm{~min}$ at $4{ }^{\circ} \mathrm{C}$. Cell lysate was centrifuged at $12,000 \mathrm{rpm}$ for $15 \mathrm{~min}$ at $4^{\circ} \mathrm{C}$ and the supernatant was collected, followed by quick freezing. Protein content was determined using Bradford reagent according to the manufacture's instruction. Equal amounts of protein (40 ug) were loaded per lane onto 8\% SDS-PAGE gel. Protein was transferred to PVDF membranes and subsequently blocked in 5\% skim milk for $30 \mathrm{~min}$ at room temperature. Anti-iNOS (1:1000 dilution; Cell Signaling Technology) antibodies were employed in $1 \%$ skim milk. The membrane was incubated with the primary antibody for $1 \mathrm{~h}$ at room temperature. After washing three times with TBST, the immunoreactive bands were visualized by using immunopure peroxidase conjugated goat anti-rabbit IgG (1:10000 dilution; Pierce, Rockford, IL, USA). The Blot was washed three times and then developed by enhanced chemiluminescence (iNtRON Biotechnology, Seongnam, Korea).

\section{Results and Discussion}

Isolation of Compounds 1-9 from $E$. alatus Leaves and Twigs. The methanolic extract of E. alatus leaves and twigs was suspended in water and successively partitioned with $\mathrm{CHCl}_{3}$, EtOAc and $n-\mathrm{BuOH}$. Each fraction was evaluated for its inhibitory activity on NO production in LPS-stimulated RAW264.7 cells. Among the fractions, the $\mathrm{CHCl}_{3}$ soluble fraction showed the greatest inhibitory activity on NO production in RAW264.7 cells (Table 2). The $\mathrm{CHCl}_{3}$ $(112 \mathrm{~g})$ was further subjected to repeated column chromatography to yield one new $C_{32}$ reissantane-type triterpene together with eight arborane, freidelane, oleanane, ursanetype triterpenes. Eight known compounds were identified as isoarborinol (2), ${ }^{11}$ friedelin (3), ${ }^{1}$ abruslactone A (4), ${ }^{2} 3 \beta, 22 \alpha$ dihydroxyolean-12-en-29-oic acid (5), ${ }^{3} 3 \alpha, 22 \alpha$-dihydroxyolean-12-en-29-oic acid (6), ${ }^{12} 3 \alpha, 22 \beta$-dihydroxyolean-12en-29-oic acid (7), ${ }^{13} 22 \alpha$-hydroxy-3-oxoolean-12-en-29-oic acid (8), ${ }^{14}$ demethylregelin $(9)^{15}$ respectively, by comparison of spectroscopic data with those previously reported (Figure 1). Compounds 2 and 4-9 are reported for the first time from this plant.

Structural Elucidation of Compound 1. Compound $\mathbf{1}$ was obtained as white amorphous powder with $[\alpha]_{\mathrm{D}}^{25}+72.0$ (c $0.1, \mathrm{MeOH})$. Its IR spectrum showed the presence of $\mathrm{OH}$ group $\left(3477 \mathrm{~cm}^{-1}\right)$ and exomethylene $\left(889 \mathrm{~cm}^{-1}\right)$. The molecular formula of $\mathbf{1}$ was determined as $\mathrm{C}_{32} \mathrm{H}_{54} \mathrm{O}$ from 

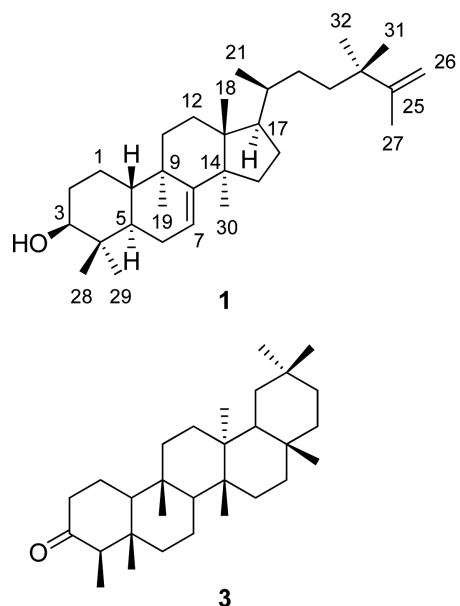

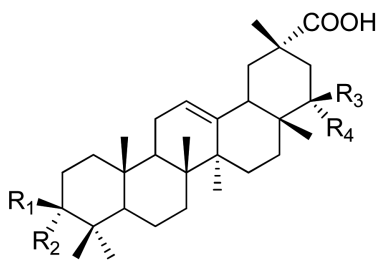

$5 \mathrm{R}_{1}=\mathrm{OH}, \mathrm{R}_{2}=\mathrm{H}, \mathrm{R}_{3}=\mathrm{H}, \mathrm{R}_{4}=\mathrm{OH}$ $6 \mathrm{R}_{1}=\mathrm{H}, \mathrm{R}_{2}=\mathrm{OH}, \mathrm{R}_{3}=\mathrm{H}, \mathrm{R}_{4}=\mathrm{OH}$ $7 \mathrm{R}_{1}=\mathrm{H}, \mathrm{R}_{2}=\mathrm{OH}, \mathrm{R}_{3}=\mathrm{OH}, \mathrm{R}_{4}=\mathrm{H}$ $8 \mathrm{R}_{1}=\mathrm{R}_{2}=\mathrm{O}, \mathrm{R}_{3}=\mathrm{H}, \mathrm{R}_{4}=\mathrm{OH}$

Figure 1. Structures of compounds 1-9 isolated from $\mathrm{CHCl}_{3}$ fraction of E.alatus leaves and twigs.

$[\mathrm{M}]^{+}$ion peak at $m / z 454.4202$ (calc. 454.4175 ) in HREIMS. The ${ }^{1} \mathrm{H}-\mathrm{NMR}$ spectrum of $\mathbf{1}$ displayed signals due to nine methyl groups; seven singlets corresponding to tertiary methyl groups $\left(\delta_{\mathrm{H}} 0.76,0.84,0.94,0.99,0.99,1.00,1.04\right)$, one doublet of a secondary methyl group $\left(\delta_{\mathrm{H}} 0.85, J=6.6\right.$ $\mathrm{Hz})$ and one vinylic methyl group $\left(\delta_{\mathrm{H}} 1.66\right)$. The ${ }^{1} \mathrm{H}-\mathrm{NMR}$ spectrum also showed signals assignable to one oxymethine proton at $\delta_{\mathrm{H}} 3.41$, one olefinic at $\delta_{\mathrm{H}} 5.15(1 \mathrm{H}, \mathrm{dd}, J=6.5,1.6$ $\mathrm{Hz})$ and one exomethylene at $\left[\delta_{\mathrm{H}} 4.66(1 \mathrm{H}\right.$, br s $), 4.72(1 \mathrm{H}$, br s)]. The ${ }^{13} \mathrm{C}-\mathrm{NMR}$ spectrum exhibited 32 carbon signals sorted by DEPT experiment as nine methyl groups, ten methylenes (including one $s p^{2}$ carbon at $\delta_{\mathrm{C}} 109.3$ ), six methines (including one oxygenated at $\delta_{\mathrm{C}} 76.5$ and one olefinic carbon at $\left.\delta_{\mathrm{C}} 117.6\right)$ and seven quaternary carbons. The location of $\mathrm{OH}$ group was evidenced by HMBC correlations between C-3 ( $\delta \mathrm{c} 76.5)$ and Me-28 ( $\left.\delta_{\mathrm{H}} 0.94\right), \mathrm{Me}-29$ $\left(\delta_{\mathrm{H}} 0.76\right)$. The relative configuration of $\mathrm{H}-3$ was determined as equatorial position from the small coupling constant of $\mathrm{H}$ $3\left(\delta_{\mathrm{H}} 3.41\right.$, br s $){ }^{16}$

Further structural details were obtained by two dimensional NMR experiments (COSY, HSQC, and HMBC), which coupled with literature data, allowed unambiguous assignment of all carbon signals (Table 1). The elucidated basal structure of 1 was very closed to the series of 19(10 $\rightarrow 9)$ abeo- $8 \alpha, 9 \beta, 10 \alpha$-euphane triterpene, which was first time found from Mallotous stenanthusz ${ }^{17}$ also called as reissantane-type triterpene. From the ${ }^{1} \mathrm{H}-{ }^{1} \mathrm{H}$ COSY correlations between H-10 and H-5, H-5 and H-6, H-6 and H-7, and the
Table 1. NMR data of compound $\mathbf{1}$ in $\mathrm{CDCl}_{3}{ }^{a}$

\begin{tabular}{|c|c|c|c|c|}
\hline pos. & $\delta_{\mathrm{H}}(500 \mathrm{MHz})$ & $\begin{array}{l}\delta_{\mathrm{C}} \\
(125 \mathrm{MHz})\end{array}$ & $\mathrm{HMBC}^{b}(\mathrm{H} \rightarrow \mathrm{C})$ & $\begin{array}{l}\operatorname{COSY}^{b} \\
(\mathrm{H} \rightarrow \mathrm{H})\end{array}$ \\
\hline 1 & $1.3-4.6 \mathrm{~m}$ & 19.8 & 3,9 & 2,10 \\
\hline 2 & $\begin{array}{l}1.64-1.70 \mathrm{~m}, 1.70- \\
1.79 \mathrm{~m}\end{array}$ & 28.5 & 4 & 1,3 \\
\hline 3 & $3.41 \mathrm{br} \mathrm{s}$ & 76.5 & 30,31 & 2 \\
\hline 4 & & 38.6 & & \\
\hline 5 & $1.88-1.97 \mathrm{~m}$ & 35.2 & $1,4,10$ & 6,10 \\
\hline $6_{\alpha}$ & $2.09-2.15 \mathrm{~m}$ & 24.1 & $4,5,7,8,20,29$ & 5,7 \\
\hline $6_{\beta}$ & $1.78-1.87 \mathrm{~m}$ & & & \\
\hline 7 & $5.15 \mathrm{dd}(6.5,1.6)$ & 117.6 & $5,6,9,14$ & 6 \\
\hline 8 & & 156.2 & & \\
\hline 9 & & 36.3 & & \\
\hline 10 & $1.11-1.15 \mathrm{~m}$ & 46.7 & & 1,5 \\
\hline $11_{\alpha}$ & $1.56-1.67 \mathrm{~m}$ & 32.2 & $8,9,12,13$ & \\
\hline $11_{\beta}$ & $1.35-1.46 \mathrm{~m}$ & & & \\
\hline $12_{\alpha}$ & $1.82-1.94 \mathrm{~m}$ & 33.7 & $8,17,30$ & \\
\hline $12_{\beta}$ & $1.68-1.79 \mathrm{~m}$ & & & \\
\hline 13 & & 42.7 & & \\
\hline 14 & & 52.7 & & \\
\hline $15_{\alpha}$ & $1.32-1.45 \mathrm{~m}$ & 33.6 & $9,13,14,18$ & \\
\hline $16_{\alpha}$ & $1.87-1.97 \mathrm{~m}$ & 28.1 & $13,14,17$ & \\
\hline $16_{\beta}$ & $1.15-1.26 \mathrm{~m}$ & & & \\
\hline 17 & & 53.8 & 18 & 16,20 \\
\hline 20 & $1.25-1.34 \mathrm{~m}$ & 36.9 & 23 & 17,21 \\
\hline 22 & $\begin{array}{l}0.77-0.83 \mathrm{~m}, 1.17- \\
1.23 \mathrm{~m}\end{array}$ & 30.5 & & 23 \\
\hline 23 & $\begin{array}{l}1.14-1.21 \mathrm{~m}, 1.37- \\
1.43 \mathrm{~m}\end{array}$ & 37.4 & & \\
\hline 24 & & 38.7 & & \\
\hline 25 & & 152.4 & & \\
\hline 26 & 4.66 br s, 4.72 br s & 109.3 & 24,27 & \\
\hline $18-\mathrm{CH}_{3}$ & $0.84 \mathrm{~s}$ & 23.6 & $12,13,14,17$ & \\
\hline $19-\mathrm{CH}_{3}$ & $1.04 \mathrm{~s}$ & 21.1 & $8,9,10,11$ & \\
\hline $21-\mathrm{CH}_{3}$ & $0.85 \mathrm{~d}(6.6)$ & 18.7 & $17,22,23$ & 20 \\
\hline 27- $\mathrm{CH}_{3}$ & $1.66 \mathrm{~s}$ & 19.4 & $24,25,26$ & \\
\hline $28-\mathrm{CH}_{3}$ & $0.94 \mathrm{~s}$ & 25.2 & $3,4,5$ & \\
\hline $29-\mathrm{CH}_{3}$ & $0.76 \mathrm{~s}$ & 19.7 & $3,4,5,28$ & \\
\hline $30-\mathrm{CH}_{3}$ & $1.00 \mathrm{~s}$ & 28.1 & $8,14,15$ & \\
\hline $31-\mathrm{CH}_{3}$ & $0.99 \mathrm{~s}$ & 27.2 & $23,24,25,32$ & \\
\hline $32-\mathrm{CH}_{3}$ & $0.99 \mathrm{~s}$ & 27.4 & $23,24,25,31$ & \\
\hline
\end{tabular}

${ }^{a}$ All assignments were made by extensive analysis of $1 \mathrm{D}$ and $2 \mathrm{D}$ NMR. ${ }^{b}$ Main observed HMBC and COSY correlations are presented.

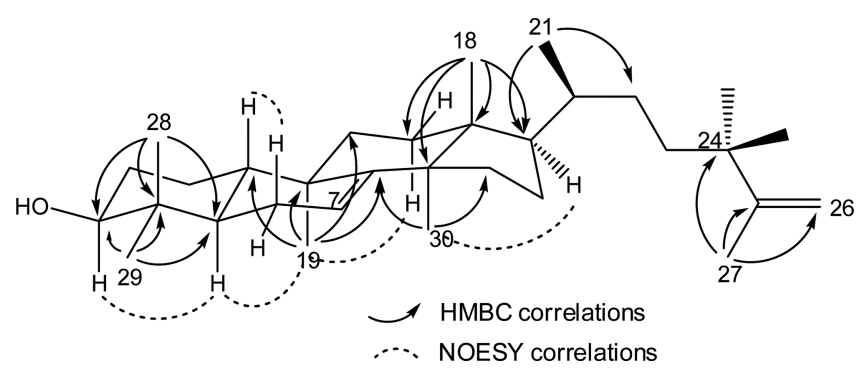

Figure 2. The selected HMBC and NOESY correlations in compound 1. 
Table 2. Inhibitory effects of total extract and each fraction of $E$. alatus leaves and twigs on NO production in LPS-stimulated RAW264.7 cells

\begin{tabular}{lccc}
\hline & $\begin{array}{c}\text { Concentration } \\
(\mu \mathrm{g} / \mathrm{mL})\end{array}$ & Nitrite $(\mu \mathrm{M})$ & Viability (\%) \\
\hline $\mathrm{Ctrl}^{a}$ & & $3.8 \pm 0.3$ & $100.0 \pm 5.5$ \\
$\mathrm{LPS}^{b}$ & & $15.5 \pm 0.6$ & $95.9 \pm 6.3$ \\
Total extract & 10 & $9.4 \pm 0.2^{*}$ & $96.6 \pm 4.1$ \\
& 100 & $5.7 \pm 0.0^{*}$ & $96.4 \pm 2.2$ \\
$\mathrm{CHCl}_{3}$ fr. & 10 & $4.5 \pm 0.1^{*}$ & $93.9 \pm 2.5$ \\
& 100 & $3.9 \pm 0.0^{*}$ & $95.7 \pm 3.1$ \\
EtOAc fr. & 10 & $8.8 \pm 0.4^{*}$ & $99.0 \pm 2.0$ \\
& 100 & $7.6 \pm 0.1^{*}$ & $92.8 \pm 1.1$ \\
$n$-BuOH fr. & 10 & $13.0 \pm 0.6$ & $91.9 \pm 2.3$ \\
& 100 & $12.2 \pm 0.5$ & $90.5 \pm 4.5$ \\
Aqueous fr. & 10 & $14.6 \pm 0.8$ & $94.8 \pm 3.2$ \\
& 100 & $13.9 \pm 0.2$ & $95.6 \pm 2.1$ \\
\hline
\end{tabular}

${ }^{a}$ Value of RAW264.7 cells not treated with LPS. ${ }^{b}$ Value of RAW264.7 cells treated with $100 \mathrm{ng} / \mathrm{mL}$ LPS for $24 \mathrm{~h}$. Mean value is significantly different $\left({ }^{*} P<0.001\right)$ from the value of the LPS-treated.

HMBC correlations of Me-19 with C-8, C-9, C-10 and C-11, it was suggested that $\mathbf{1}$ was reissantane-type triterpene with double bond between C-7 and C-8 (Figure 2). The stereochemistry of $\mathbf{1}$ was determined from the cross peaks observed in NOESY spectrum between Me-19 and H-5, Me-29, between Me-28, Me-29 and H-6, between Me-30 and H-17 (Figure 2). Two extra methyl groups, Me-31 $\left(\delta_{\mathrm{H}} 0.99\right)$ and Me-32 $\left(\delta_{\mathrm{H}} 0.99\right)$ showed the same HMBC correlations with C-23, C-24 and C-25 indicating 24,24-dimethyl position. The presence of 10 carbon side chain was further supported by the characteristic fragment peaks in MS spectrum at $\mathrm{m} / \mathrm{z}$ 439 (M-Me), $421\left(\mathrm{M}-\mathrm{H}_{2} \mathrm{O}-\mathrm{Me}\right), 315$ (M-side chain), 313 (M-side chain-2H). ${ }^{18}$ The remaining exomethylene was determined at $\mathrm{C}-25$ from the HMBC correlations between C$24\left(\delta_{\mathrm{C}} 38.7\right)$ and $\mathrm{H}-26\left(\delta_{\mathrm{H}} 4.66\right.$ and 4.72$), \mathrm{H}-27\left(\delta_{\mathrm{H}} 1.66\right)$. The chemical shift $\left(\delta_{\mathrm{H}} 0.85, \mathrm{~d}, J=6.6 \mathrm{~Hz}\right)$ of $\mathrm{Me}-21$ in ${ }^{1} \mathrm{H}-$ NMR spectrum, and the positive optical rotation of 1 $\left(+72.0^{\circ}\right)$ also indicated that the relative configuration of the side chain belonged to the euphane rather than the tirucallane series. ${ }^{19}$ From above data, compound $\mathbf{1}$ was determined as a $\mathrm{C}_{32}$ reissantane-type triterpenoid which possesses extra two methyl groups at C-24 in the side chain. On the basis of these data, compound 1 was determined to be 24,24-dimethyl-reissant-7(8), 25-dien-3 $\alpha$-ol.

Anti-inflammatory Activities of Compounds 1-9 in LPSactivated RAW264.7 Cells. Inhibitory effects of compounds 1-11 on LPS-induced NO production in RAW264.7 cells were evaluated using the Griess reaction. The treatment of LPS resulted in a significant increment of nitrite concentration in the medium compared to control. Among the compounds isolated, compounds $4,5,6$, and 9 showed the strong or moderate inhibitory effects on NO production (Table 2) while the others were inactive. Oleanane-type triterpenoids $\mathbf{4 - 8}$ characteristically possessed oxygenated C-
Table 3. Inhibitory effects of compounds 4, 5, 6 and 9 on NO production induced by LPS in RAW264.7 cells

\begin{tabular}{|c|c|c|c|c|c|}
\hline & $10 \mu \mathrm{M}$ & $20 \mu \mathrm{M}$ & $50 \mu \mathrm{M}$ & $100 \mu \mathrm{M}$ & $\mathrm{IC}_{50}$ \\
\hline & \multicolumn{4}{|c|}{ Relative NO production $(\%)^{a}$} & $(\mathrm{uM})$ \\
\hline $\mathrm{Ctrl}^{b}$ & & 0.0 & \pm 2.1 & & \\
\hline $\mathrm{LPS}^{c}$ & & 100. & \pm 2.3 & & \\
\hline 4 & $97.6 \pm 1.2$ & $80.1 \pm 1.8$ & $47.6 \pm 0.2^{*}$ & $16.6 \pm 0.5^{* *}$ & 42.6 \\
\hline 5 & $93.6 \pm 0.5$ & $92.0 \pm 1.9$ & $38.8 \pm 0.4^{*}$ & $42.0 \pm 0.8^{*}$ & 53.7 \\
\hline 6 & $84.9 \pm 0.9$ & $83.3 \pm 3.1$ & $53.1 \pm 0.6^{*}$ & $34.9 \pm 0.2^{*}$ & 56.4 \\
\hline 9 & $88.0 \pm 1.1$ & $72.2 \pm 3.3$ & $23.8 \pm 0.4^{*}$ & $5.5 \pm 0.9^{* *}$ & 29.0 \\
\hline $\mathrm{L}-\mathrm{NAME}^{d}$ & & & & & 48.5 \\
\hline
\end{tabular}

${ }^{a}$ Relative NO production (\%) calculated as $100 \times($ NO of LPS + sampletreated - NO of untreated control)/(NO of LPS-treated - NO of untreated control). ${ }^{b}$ Value of RAW264.7 cells not treated with LPS. ${ }^{c}$ Value of RAW264.7 cells treated with $100 \mathrm{ng} / \mathrm{mL}$ LPS for $24 \mathrm{~h}$. NO concentration $(\mu \mathrm{M})$ of control and LPS-treated cultures were $3.2 \pm 0.1$ and $15.8 \pm 0.3$, respectively. ${ }^{~}$ NAME ( $\omega$-nitro-l-arginine methyl ester) positive control. Mean value is significantly different $\left({ }^{*} P<0.01,{ }^{* *} P<\right.$ 0.001) from the value of the LPS-treated.
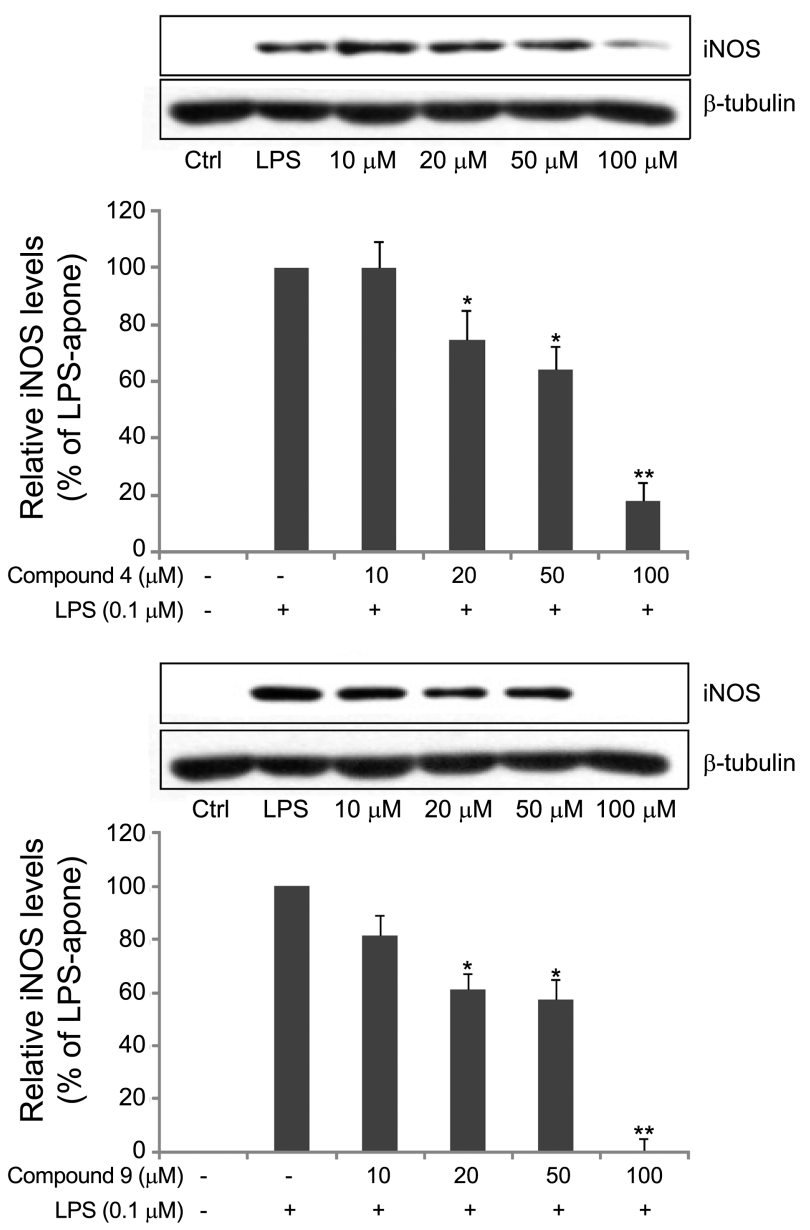

Figure 3. Inhibitory effects of compounds $\mathbf{4}$ and $\mathbf{9}$ on LPS-induced iNOS expression in RAW264.7 cells. RAW264.7 cells were pretreated with compounds 4 or 9 for $1 \mathrm{~h}$, then exposed to LPS for 24 h. Cell lysate $(40 \mu \mathrm{g}$ protein) was prepared from the cells and subjected to Western blot analysis using an antibody specific for iNOS as described in the Methods. The values shown are mean \pm SD of data from three independent experiments. Significant compared with LPS alone, ${ }^{*} P<0.01,{ }^{* *} P<0.001$. 
3, hydroxyl group at C-22 and carboxyl group at C-29. In those triterpenes, compound $\mathbf{4}$ in which hydroxyl group at $\mathrm{C}$ 22 and carboxyl group at C-29 were connected by ester linkage showed the most potent activity compared to those of compounds 5-7 with free forms of carboxyl group and hydroxyl group. In addition, compound 7 with $\beta$-hydroxy group at C-22, and compound $\mathbf{8}$ with ketone group at $\mathrm{C}-3$ were found to be inactive. At the concentration of $100 \mu \mathrm{M}$, the NO production was significantly decreased up to $20 \pm$ $1.5 \%$ and $15 \pm 0.8 \%$ of control level by the pretreatment of compounds 4 and 9, respectively. To verify whether the reduced cell numbers which were caused by the cytotoxicity of these compounds resulted in decrease of NO production, cell viability was measured employing MTT assay. All the compounds tested showed no cytotoxicity at the concentration ranging from $10 \mu \mathrm{M}$ to $100 \mu \mathrm{M}$.

Since NO has been known to be produced by iNOS in LPS-stimulated RAW264.7 cells, the inhibitory effects of compounds 4 and $\mathbf{9}$, which showed the most potent inhibitory activity on NO production, on the expression of iNOS protein were measured. Treatment of RAW264.7 cells with LPS resulted in the increment of iNOS expression and subsequent NO production. Pretreatment of RAW264.7 cells with compounds $\mathbf{4}$ or $\mathbf{9}$ significantly inhibited the expression level of iNOS protein compared to cells treated with LPSonly. The inhibition of iNOS expression was more remarkable in the treatment of compound 9 at the concentration of $100 \mu \mathrm{M}$ (Figure 3).

\section{Conclusion}

Nine triterpenenes including one new reissantane-type was isolated from E. alatus leaves and twigs. Among the compounds isolated, abruslactone A (4) and demethylregelin (9) showed the potent inhibitory activities on NO production and iNOS expression in LPS-stimulated RAW264.7 cells. Though further investigations are required to clarify the detailed anti-inflammatory actions of bioactive compounds from E. alatus, the triterpenes isolated herein are thought contribute to anti-inflammatory effects of E. alatus and might possess beneficial therapeutic potential against various inflammation-related diseases.
Acknowledgments. This work was supported by grants from the Connected Cooperation Projects of Metropolitan Economic Areas (Grant \# A004500005 to M-J Ahn), Ministry of Knowledge Economy, and also partially supported by grants from the Next-Generation BioGreen 21 Program (SSAC, grant\#: No. PJ0095062013 to M-J Ahn), and Cooperative Research Program for Agriculture Science \& Technology Development (Grant \# PJ009804 to EJ Jeong), Rural Development Administration, Republic of Korea.

\section{References}

1. Akihisa, T.; Yamamoto, K.; Tamura, T.; Iida, T.; Nambara, T.; Cheng, F. C. Chem. Pharm. Bull. 1992, 40, 789.

2. De Fatima Silva, G. D.; Duarte, L. P.; Da Silva Paes, H. C.; De Sousa, J. R.; Nonato, M. C.; Portezani, P. J. J. Brazil. Chem. Soc. 1998, 9, 461.

3. Liu, C. M.; Wang, H. X.; Wei, S. L.; Gao, K. J. Nat. Prod. 2008, 71,789 .

4. Jeong, E. J.; Yang, H.; Kim, S. H.; Kang, S. Y.; Sung, S. H.; Kim, Y. C. Food Chem. Toxicol. 2011, 49, 1394.

5. Jeong, E. J.; Cho, J. H.; Sung, S. H.; Kim, S. Y.; Kim, Y. C. Bioorg. Med. Chem. Lett. 2011, 15, 2283.

6. Mosser, D. M.; Edwards, J. P. Nature Rev. Immunol. 2008, 8, 958.

7. Adams, D. O.; Hamilton, T. A. Annu. Rev. Immuno. 1984, 2, 238.

8. Hinz, B.; Brune, K. J. Pharmacol. Exp. Ther. 2002, 300, 367.

9. Molloy, R. G.; Mannick, J. A.; Rodrick, M. L. Brit. J. Surg. 1993, $80,289$.

10. Klein, T. W. Nature Rev. Immunol. 2005, 5, 400.

11. Sun, Y.; Zhan, Y. C.; Pei, Y. H. J. Asian Nat. Prod. Res. 2007, 9, 321 .

12. Nakano, K.; Oose, Y.; Takaishi, Y. Phytochemistry 1997, 46, 1179.

13. Nakagawa, H.; Takaishi, Y.; Fujimoto, Y.; Duque, C.; Garzon, C.; Sato, M. J. Nat. Prod. 2004, 67, 1919.

14. Kutney, J. P.; Hewitt, G. M.; Lee, G.; Piotrowska, K.; Roberts, M.; Rettig, S. Can. J. Chem. 1992, 70, 1455.

15. Takaishi, Y.; Wariishi, N.; Tateishi, H.; Kawazoe, K.; Nakano, K.; Ono, Y. Phytochemistry 1997, 45, 969.

16. Jiang, Z. H.; Tanaka, T.; Hirata, H.; Fukuoka, R.; Kouno, I. Tetrahedron 1997, 53, 16999.

17. Pal, R.; Kulshreshtha, D. K.; Rastogi, R. P. Phytochemistry 1975, 14, 2253.

18. Hui, W. H.; Luk, K.; Arthur, H. R.; Loo, S. N. J. Chem. Soc. 1971, 2826.

19. Mamta, M.; Yogendra, N.; Sushil, K. Phytochemistry 2000, 54, 835 . 